\title{
Molecular Modelling of nsSNPs in GABRA2 Gene in Epilepsy and Study of Their Impact On Structure and Stability of GABRA2 Protein
}

\author{
Zehra Agha ( $\nabla$ zehranajam@gmail.com ) \\ COMSATS University Islamabad https://orcid.org/0000-0003-3413-0578 \\ Maleeha Azam \\ COMSATS University Islamabad \\ Bushra Faryal \\ COMSATS University Islamabad
}

\section{Research Article}

Keywords: Computational analysis, Seizures, Neurotransmitter, Coding variants, GABA, Brain

Posted Date: November 9th, 2021

DOl: https://doi.org/10.21203/rs.3.rs-1019527/v1

License: (9) (1) This work is licensed under a Creative Commons Attribution 4.0 International License. Read Full License 


\section{Abstract}

Epilepsy is a neurological condition characterized by abrupt, unprovoked, and recurrent seizures that are unpredictable in frequency. The objective of this analysis was to identify novel non-synonymous polymorphisms in the GABRA2 gene and determine their effect on protein structure and stability. Most pathogenic/deleterious nsSNPs were predicted using six different bioinformatic tools. Mutpred2, Mupro was used to check the impact of identified nsSNPS on protein structure and stability. The pathogenic score of SNPs was predicted using the FATHMM tool. The CONSURF webserver was used for conservation analysis of pathogenic SNPS.3-D structure of the protein was realized using SWISS-MODEL and residue position in protein visualized by Lite Mol. GeneMANIA and STRING databases were used to predict the function of interlinked gene interactions. Out of 228 nsSNPs retrieved from the dbSNP database, we identified a novel missense variant, F285S (rs41310789), as most deleterious and its possible association with epilepsy syndrome focal epilepsy. Stability and conservation analysis results interpret rs41310789 present in evolutionarily conserved regions of a gene and affect its structure. This analysis provides information regarding the impact of nsSNPs that might affect the structure and activity of GABRA2 protein. Thus, these coding variants should be taken into scrutiny while genetic screening of epileptic patients.

\section{Introduction}

Epilepsy is characterized by frequent seizure, unusual sensation, and loss of awareness in some cases and cause different health-related problems (Sirven, 2015). Repeated epileptic seizures occur due to an imbalance between inhibitory and excitatory neurotransmitters in the brain (Fisher et al., 2005). According to a study of syndromes' global burden, epilepsy stands at second position worldwide (Murray et al., 2012). All patients with seizures usually do not have epilepsy, but all patients with epilepsy experience seizures either repeated or frequent (Beghi, 2020). Epilepsy is the 4th most common neurological disorder and affects anyone regardless of age, gender, all races, and ethnicity (Asker, 2021). The definition of Epilepsy was recently updated by ILAE(International League against Epilepsy) "a short-term appearance of early signs and symptoms due to uncontrolled or synchronized neuronal action in the brain (Fisher et al., 2005). Diagnosis of epilepsy depends on the following criteria's: 1)More than two unconscionable or involuntary seizures or clusters of seizures happening in less than one day apart,(2) A single unconscionable or involuntary seizure that has a possibility of having another seizure or $60 \%$ chances of reoccurrence after two unconscionable seizures in ten years (Maloney et al., 2021) (3) Epilepsy syndrome are either genetic or idiopathic (unknown cause) (Falco-Walter et al., 2018). A severe form of epilepsy is present primarily in old age people and infants, and they are at high risk. Typically, brain injury is considered a cause of epilepsy in affected individuals, resulting from abnormal circuit activity in the brain. However, several other leading causes of epilepsy are genetics (Sun et al., 2021), brain abnormalities, developmental disorders, metabolic changes, immune system abnormalities, tumours, prenatal injury, and unknown causes. In about $50 \%$ of global cases, epilepsy causes are still unknown (Beghi et al., 2019).In minor cases, the cause of epilepsy is known. Existing literature has provided comprehensive knowledge about the pathogenic mechanism of epilepsies, including variations in ion channels, abnormal release or uptake of neurotransmitters, and neuronal loss (Fu et al., 2020).

According to World Health Organization, more than 3million people in the US and 50 million people globally have epilepsy, making it one of the prevalent neurological conditions (Goldenberg, 2010). Higher incidence and 
prevalence of epilepsy are present in developing countries; nearly $90 \%$ of individuals who reside there have epilepsy (Owolabi et al., 2020). Despite many new kinds of research, epilepsy remains a significant cause of mortality and disability globally. Due to several economic, ethnic, and social reasons, sub-Saharan Africa countries have many individuals living with epilepsy and bear an enormous disorder burden (Paul et al., 2012).

There is a considerable treatment gap in low and middle-income country residents because people often stigmatize epilepsy and do not get proper treatment (Thijs et al., 2019). Overall, $75 \%$ of epileptic patients did not get proper treatment due to poor social and economic situations in developing countries (Espinosa-Jovel et al., 2018). According to the WHO estimate, $70 \%$ of people live seizure-free life if adequately diagnosed and appropriately treated with antiepileptic drugs (Brodie et al., 2012). Epilepsy is also a prevalent neurological disorder in Pakistan, accounting for $1 \%$ of the Pakistani population (lqbal et al., 2018).In the Pakistani population, 9.99 over 1000 people have epilepsy. A higher number of cases belongs to older people over 30, i.e., 2 million individuals and 1/10th of the global burden of epilepsy in Pakistan (Siddiqui et al., 2015). A better health system will help reduce disease burden with cost-effective treatment, increased diagnostic capabilities, and drug supply (Megiddo et al., 2016).

Gamma-Aminobutyric acid is a primary inhibitory neurotransmitter present in the human cerebrum. It acts

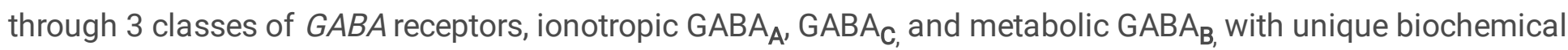
and electrophysical properties. In humans, GABA plays a crucial role in the development of the brain.GABA $A$ receptors are ligand-gated chloride ion channels present all over the human brain(Arias et al., 2014).GABRA2 is a protein-coding gene and highly expressed in the hippocampus and mediates synaptic transmission. GABRA2 gene is positioned on the short $\mathrm{p}$ arm of Chr.no 4 and localized more precisely to the subtelomeric region of band $4 \mathrm{p} 21$. This gene has 14 exons, out of which nine exons are present in the coding region. A total of 8520 nucleotides are present in the whole GABRA2 gene.

GABRA2 gene plays a significant role in early infantile epileptic encephalopathy (EIEE). This disease affects newborns, usually within the first three months. This gene is involved in the synaptic neurotransmission pathway and affects the GABAergic inhibition of excitatory and inhibitory neurons. Mutations in the GABRA2 gene are implicated in several neurological disorders, including epilepsy. Multiple genome-wide association studies identified nsSNPs associated with an increased risk of epilepsy. Another study by Naama Orenstein et al. also positions GABRA2 as a potential candidate for Early-onset epileptic encephalopathy(EOEE) (Orenstein et al., 2018).

Mapping GABRA2 variants to protein structure showed they were located near the desensitization gate, critical regions for GABAergic receptors' proper functioning (Sanchis-Juan et al., 2020), and GABA energic synapse pathway is involved in epilepsy.

There is a bloom in bioinformatics tools during the sars covid-19 pandemic and increasingly used to analyze gene regulation and protein expression in molecular biology analysis (Mehmood, 2014). The bioinformatics tools help us understand the role of nsSNPs in protein destabilization by predicting amino acid change in a protein sequence. Moreover, homology modelling was performed to evaluate the crucial role of amino acid change on protein structure and its impacts on stability. 
This study's main objective is to perform computational analysis to predict the most deleterious coding polymorphisms and identify their pathogenic effect on protein structure using different tools.

\section{Materials And Methods \\ 2.1. Data source}

All the literature reviewed related to epilepsy, GABRA2 gene,nsSNPs was searched using google scholar, science direct, Pubmed, and NCBI databases. We use keywords epilepsy, genetic association,nsSNPs, and human protein to search literature. As its a new study, we only select those publications that prove the association of nsSNPs in epilepsy.

\subsection{Retrieval of SNPs}

All the information about GABRA2 SNPs was gathered from dbSNP, a database established by National Center for Biotechnology Information (https://cutt.ly/2jotOe4). The amino acid sequence of the protein in FASTA format were collected from NCBI (NP_000798.2). Polymorphisms for GABRA2 were obtained from NCBI using different filters like missense, non-synonymous, human, coding, nonsense, and intronic.

\subsection{Identification of most deleterious nsSNPs}

We use six different bioinformatics tools to predict the effect of nsSNPs on GABRA2 protein structure. These tools include SIFT(Vaser et al., 2016), PROVEAN (Choi and Chan, 2015), PolyPhen-2(Adzhubei et al., 2010), PANTHER(Tang and Thomas, 2016), PhD-SNP, and SNP\&GO(Thusberg et al., 2011) (Table 1). We only include SNPs that are predicted as deleterious by software.

\subsection{Stability analysis}

We used two different bioinformatic tools to check the impact of pathogenic single nucleotide polymorphisms on protein structure and stability (Table 2). Mupro (Cheng et al., 2006) used artificial intelligence technology to predict the stability score, while Mutpred2(Pejaver et al., 2020) used 14 different molecular and structural functions to realize the impacts of nsSNPs on protein structure.

\subsection{Disease association analysis}

We use FATHMM(Hassan et al., 2019) to predict the phenotypic and molecular significance of single point mutations and their impact on the human genome. This software use hidden HMMs(Markov models) to predict the effect of both coding variants(missense or nsSNPs) and non-coding variants in the human genome(Shihab et al., 2013).

\subsection{Conservation analysis}

Consurf was used to characterize variable and conserved areas of GABRA2. Fifteen years ago, the Consurf web software was developed to visualize evolutionarily conserved regions present in a protein sequence(Ashkenazy et al., 2010). This server predicts the degree of amino acid conservation(Ashkenazy et al., 2016).

\subsection{Three-dimensional structure of the protein.}


3-D structure of GABRA2 protein was generated by SWISS-MODEL web server (Sharma et al., 2020), and residue position in protein sequence was visualized by Lite Mol(Xing et al., 2019).GeneMANIA and STRING database (Szklarczyk et al., 2021)is used to predict the function of interlinked gene interactions (Montojo et al., 2014). GeneMANIA and STRING are online databases that predict genes' interactions with each other and their common associations like functional/molecular pathways, genetic interactions,co-expression, and other typical interactions between them(Szklarczyk et al., 2019). In the case of GABRA2, we found everyday neurotransmitter activity and neuron-neuron synaptic transmission with other genes(Warde-Farley et al., 2010).

\section{Results}

\subsection{Distribution of SNPs}

A total of 36912 SNPs present in human GABRA2 were retrieved from the dbSNP database. On other selection, 34375 SNPs were intronic variants, 142 as synonymous, five pathogenic variants, and 228 as non-synonymous SNPs (Figure 1). According to NCBI data, non-synonymous SNPs contribute to only $0.62 \%$ of all the SNPs reported in the human GABRA2 gene.

\subsection{Prediction of most deleterious nsSNPs in GABRA2}

Seven different algorithms, SIFT, PROVEAN, Polyphen, Panther, SNP\&GO, PhD-SNP, and FATHMM, were applied to predict the impact of pathogenic nsSNPs on protein stability and structure. Fathmm also predicts specific epileptic syndromes associated with these SNPs (Table 3). Out of 228 non-synonymous single nucleotide polymorphisms, only six were predicted as deleterious/disease/damaging, while FATHMM predicts only F285S as damaging, causing focal epilepsy. Out of these six nsSNPs, only F285S was predicted as most pathogenic.

\subsection{Protein stability analysis}

After finding the most deleterious nsSNP, we subjected it to Mupro and MutPred algorithms to find its impact on protein stability. Mupro uses a scale between 1 and -1 to give a predictability score and a score of fewer than 0 means protein stability decreases due to mutation, while a score of more than 0 means protein stability increases (Table 4).

\subsection{Conservation analysis}

Certain variations in the human genome cause multiple diseases and affect human health. Consurf is the webserver used for predicting conserved evolutionary domains in a protein sequence. In order to check our novel nsSNP conservation frequency, we manipulated the original protein structure and subjected it to a consurf web server. The analysis results showed that F285S is present in a conserved region and a buried residue (Figure 2).

\subsection{Structural modeling and comparison of variants}

The SWISS-MODEL database generated several models for both native and mutant types of protein. We choose 6huj.1.D template for native and 6i53.1.B for mutant protein sequence. Lite Mol was used to visualize mutant protein sequences and marked mutations on 3-D structure (Figure 3). The blue-coloured balls on 3D structures show the location of identified nsSNPs on protein. 


\subsection{STRING database networks}

To better understand GABRA2 gene function, it is vital to study their interactions with other genes. Consequently, Gene Mania and STRING databases were used to scan genes that interact with GABRA2 protein.GABRA2 gene shows direct interactions with NSF, UBQLN1, GABRA3, GABRA4, GABRA5, and GABARAP gene, respectively (Figure 4).

\section{Discussion}

Although most single nucleotide polymorphisms were reported in intronic regions of the GABRA2 gene, in this analysis, we reported a missense variant of GABRA2 present in the coding region. SNPs are single nucleotide substitutions found in specific locations impacting the exonic regions of the human genome (Vallejos-Vidal et al., 2020). These substitutions are responsible for changing protein structure and function, affecting human health, and causing multiple disorders (Robert and Pelletier, 2018). These single nucleotide polymorphisms cause less than $1 \%$ genetic change in the overall global population. We can easily access the number and molecular sequence of these SNPs stored in computational databases.

Using bioinformatics tools and algorithms helps us quickly design and execute an analysis without laborious and time-consuming experimental work (Khatun et al., 2020). This type of analysis of nsSNPs is substantiating to refine the molecular characterization of nsSNPs that would contribute massive support in personalized medication development (Loganathan et al., 2021).

In a GWAS study, Butler \& $\mathrm{K}$ identified a de novo missense variant present in GABRA2 causing early-onset of epilepsy(Butler et al., 2018). Another study confirmed de novo missense mutation in GABRA2 at chromosome no four by Sanger sequencing (Orenstein et al., 2018).

This insilico study aims to identify the role of novel nsSNPs identified using all computational tools and visualize their effect on protein structure and function (Gong et al., 2021). We collected all the GABRA2 gene SNPs from the dbSNP database and subjected only nsSNPs to all seven bioinformatics tools. Total six missense variants (V80A, T43A, F285S, T70I, P79S,F93) were predicted as pathogenic by all tools. While most of them picked F285S as the most deleterious nsSNP in gene sequence and caused a decrease in protein stability upon nucleotide substitution in the human genome.As a result of a change in amino acid F285S variant cause focal epilepsy.

The results of conservation analysis show that this variant is a buried residue and present in a conserved domain of the GABRA2 protein sequence. Substitution of conserved amino acids disrupts protein's biological activities because they are located in biologically active domains of the protein (Miller and Kumar, 2001).

Homology modelling showed mutant protein type resembles 6huj.1.D template of GABRA1 gene, which is closet analogue of GABRA2 gene. A study done by Johannsson, Katrine et al. reported

GABRA1 mutations play a significant role in severe and benign epilepsy syndromes (Johannesen et al., 2016).

\section{Conclusion}


In this study, we explored the disease-causing GABRA2 gene by assessing the effect of non-synonymous SNPs by various online computational servers. There are 36912 single nucleotide polymorphisms within a GABRA2 gene, 228 identified as nsSNPs, 34375 as intronic, five pathogenic, and 142 as synonymous. Initially we choose six SNPs rs17852044, rs41305781, rs41310789, rs74440199, rs76519302, rs199725032 to select the most deleterious nsSNPs and to increase the precision of the analysis.Among these six, only one missense variant that is rs41310789 was found to be most pathogenic. This predicted nsSNPs were both causing epilepsy syndrome, focal epilepsy, and certain CNS disorders or cognitive diseases.

Moreover, a wet lab molecular and functional analysis is necessary further to elucidate these nsSNPs in epilepsy and its related disorders.

\section{Declarations}

\section{Declaration of Competing Interest}

The authors declare that they have no known competing financial interests or personal relationships that could have influenced the work reported in this paper.

\section{Authors Contributions}

All the authors contributed equally in study design and conception.

\section{Funding sources}

This research did not receive any specific grant from funding agencies in the public, commercial, or not-forprofit sectors.

\section{References}

1. Adzhubei, I.A., Schmidt, S., Peshkin, L., Ramensky, V.E., Gerasimova, A., Bork, P., Kondrashov, A.S., Sunyaev, S.R., 2010. A method and server for predicting damaging missense mutations. Nat. Methods. https://doi.org/10.1038/nmeth0410-248

2. Arias, A.J., Covault, J., Feinn, R., Pond, T., Yang, B.-Z., Ge, W., Oncken, C., Kranzler, H.R., 2014. A GABRA2 Variant Is Associated with Increased Stimulation and Alcohol Alcohol. 49, 1-9. https://doi.org/10.1093/alcalc/agt163

3. Ashkenazy, H., Abadi, S., Martz, E., Chay, O., Mayrose, I., Pupko, T., Ben-Tal, N., 2016. ConSurf 2016: an improved methodology to estimate and visualize evolutionary conservation in macromolecules. Nucleic Acids Res. 44, W344-W350. https://doi.org/10.1093/nar/gkw408

4. Ashkenazy, H., Erez, E., Martz, E., Pupko, T., Ben-Tal, N., 2010. ConSurf 2010: calculating evolutionary conservation in sequence and structure of Nucleic Acids Res. 38, W529-33. https://doi.org/10.1093/nar/gkq399

5. Asker, A.U., 2021. Assessment of the Quality of Life in Patients with Epilepsy in the Populous Region of Baku. Neuroscience 5, 35-40. 
6. Beghi, E., 2020. The Epidemiology of Epilepsy. Neuroepidemiology 54, 185-191. https://doi.org/10.1159/000503831

7. Beghi, E., Giussani, G., Nichols, E., Abd-Allah, F., Abdela, J., Abdelalim, A., Abraha, H.N., Adib, M.G., Agrawal, S., Alahdab, F., Awasthi, A., Ayele, Y., Barboza, M.A., Belachew, A.B., Biadgo, B., Bijani, A., Bitew, H., Carvalho, F., Chaiah, Y., Daryani, A., Do, H.P., Dubey, M., Endries, A.Y.Y., Eskandarieh, S., Faro, A., Farzadfar, F., Fereshtehnejad, S.-M., Fernandes, E., Fijabi, D.O., Filip, I., Fischer, F., Gebre, A.K., Tsadik, A.G., Gebremichael, T.G., Gezae, K.E., Ghasemi-Kasman, M., Weldegwergs, K.G., Degefa, M.G., Gnedovskaya, E. V, Hagos, T.B., Haj-Mirzaian, Arvin, Haj-Mirzaian, Arya, Hassen, H.Y., Hay, S.I., Jakovljevic, M., Kasaeian, A., Kassa, T.D., Khader, Y.S., Khalil, I., Khan, E.A., Khubchandani, J., Kisa, A., Krohn, K.J., Kulkarni, C., Nirayo, Y.L., Mackay, M.T., Majdan, M., Majeed, A., Manhertz, T., Mehndiratta, M.M., Mekonen, T., Meles, H.G., Mengistu, G., Mohammed, S., Naghavi, M., Mokdad, A.H., Mustafa, G., Irvani, S.S.N., Nguyen, L.H., Nixon, M.R., Ogbo, F.A., Olagunju, A.T., Olagunju, T.O., Owolabi, M.O., Phillips, M.R., Pinilla-Monsalve, G.D., Qorbani, M., Radfar, A., Rafay, A., Rahimi-Movaghar, V., Reinig, N., Sachdev, P.S., Safari, H., Safari, S., Safiri, S., Sahraian, M.A., Samy, A.M., Sarvi, S., Sawhney, M., Shaikh, M.A., Sharif, M., Singh, G., Smith, M., Szoeke, C.E.I., Tabarés-Seisdedos, R., Temsah, M.-H., Temsah, O., Tortajada-Girbés, M., Tran, B.X., Tsegay, A.A.T., Ullah, I., Venketasubramanian, N., Westerman, R., Winkler, A.S., Yimer, E.M., Yonemoto, N., Feigin, V.L., Vos, T., Murray, C.J.L., 2019. Global, regional, and national burden of epilepsy, 1990\&\#x2013;2016: a systematic analysis for the Global Burden of Disease Study 2016. Lancet Neurol. 18, 357-375. https://doi.org/10.1016/S1474-4422(18)30454-X

8. Brodie, M.J., Barry, S.J.E., Bamagous, G.A., Norrie, J.D., Kwan, P., 2012. Patterns of treatment response in newly diagnosed epilepsy. Neurology 78, 1548 LP - 1554.

https://doi.org/10.1212/WNL.0b013e3182563b19

9. Butler, K.M., Moody, O.A., Schuler, E., Coryell, J., Alexander, J.J., Jenkins, A., Escayg, A., 2018. De novo variants in GABRA2 and GABRA5 alter receptor function and contribute to early-onset epilepsy. Brain 141, 2392-2405. https://doi.org/10.1093/brain/awy171

10. Cheng, J., Randall, A., Baldi, P., 2006. Prediction of protein stability changes for single-site mutations using support Proteins 62,1125-1132. https://doi.org/10.1002/prot.20810

11. Choi, Y., Chan, A.P., 2015. PROVEAN web server: a tool to predict the functional effect of amino acid substitutions and indels. Bioinformatics 31, 2745-2747. https://doi.org/10.1093/bioinformatics/btv195

12. Espinosa-Jovel, C., Toledano, R., Aledo-Serrano, Á., García-Morales, I., Gil-Nagel, A., 2018. Epidemiological profile of epilepsy in low income populations. Seizure 56, 67-72.

https://doi.org/https://doi.org/10.1016/j.seizure.2018.02.002

13. Falco-Walter, J.J., Scheffer, I.E., Fisher, R.S., 2018. The new definition and classification of seizures and epilepsy. Epilepsy Res. 139, 73-79. https://doi.org/https://doi.org/10.1016/j.eplepsyres.2017.11.015

14. Fisher, R.S., van Emde Boas, W., Blume, W., Elger, C., Genton, P., Lee, P., Engel, J.J., 2005. Epileptic seizures and epilepsy: definitions proposed by the International League Against Epilepsy (ILAE) and the International Bureau for Epilepsy (IBE). Epilepsia 46, 470-472. https://doi.org/10.1111/j.00139580.2005.66104.x

15. Fu, J., Tao, T., Li, Z., Chen, Y., Li, J., Peng, L., 2020. The roles of ER stress in epilepsy: Molecular mechanisms and therapeutic implications. Biomed. Pharmacother. 131, 110658.

https://doi.org/https://doi.org/10.1016/j.biopha.2020.110658 
16. Goldenberg, M.M., 2010. Overview of drugs used for epilepsy and seizures: etiology, diagnosis, and treatment. P T 35, 392-415.

17. Gong, T., Yang, L., Shen, F., Chen, H., Pan, Z., Zhang, Q., Jiang, Y., Zhong, F., Yang, P., Zhang, Y., 2021. Computational and Mass Spectrometry-Based Approach Identify Deleterious Mol. . https://doi.org/10.3390/molecules26154653

18. Hassan, M.S., Shaalan, A.A., Dessouky, M.I., Abdelnaiem, A.E., ElHefnawi, M., 2019. Evaluation of computational techniques for predicting single nucleotide variants pathogenicity. Genomics 111, 869882. https://doi.org/https://doi.org/10.1016/j.ygeno.2018.05.013

19. Iqbal, M.J., Wasim, M., Rashid, U., Zeeshan, N., Ali, R., Nayyab, S., Habib, S., Manzoor, B., Zahid, N., 2018. generalized tonic clonic seizures and children with childhood absence epilepsy. J. Chin. Med. Assoc. 81, 665-669. https://doi.org/10.1016/j.jcma.2018.05.001

20. Johannesen, K., Marini, C., Pfeffer, S., Møller, R.S., Dorn, T., Niturad, C.E., Gardella, E., Weber, Y., Søndergård, M., Hjalgrim, H., Nikanorova, M., Becker, F., Larsen, L.H.G., Dahl, H.A., Maier, O., Mei, D., Biskup, S., Klein, K.M., Reif, P.S., Rosenow, F., Elias, A.F., Hudson, C., Helbig, K.L., Schubert-Bast, S., Scordo, M.R., Craiu, D., Djémié, T., Hoffman-Zacharska, D., Caglayan, H., Helbig, I., Serratosa, J., Striano, P., De Jonghe, P., Weckhuysen, S., Suls, A., Muru, K., Talvik, I., Talvik, T., Muhle, H., Borggraefe, I., Rost, I., Guerrini, R., Lerche, H., Lemke, J.R., Rubboli, G., Maljevic, S., 2016. Phenotypic spectrum of GABRA1: From generalized epilepsies to severe epileptic encephalopathies. Neurology 87, 1140-1151. https://doi.org/10.1212/WNL.0000000000003087

21. Khatun, M.S., Shoombuatong, W., Hasan, M.M., Kurata, H., 2020. Evolution of Sequence-based Bioinformatics Tools for Protein-protein Interaction Prediction. Curr. Genomics 21, 454-463. https://doi.org/10.2174/1389202921999200625103936

22. Loganathan, L., Kuriakose, B.B., Mushfiq, S., Muthusamy, K., 2021. Mechanistic insights on nsSNPs on binding site of renin and cytochrome P450 proteins: A computational perceptual study for pharmacogenomics evaluation. J. Cell. Biochem. 122, 1460-1474.

https://doi.org/https://doi.org/10.1002/jcb.30069

23. Maloney, E.M., , É.J., Costello, D.J., 2021. Causes and classification of first unprovoked seizures and newlydiagnosed epilepsy in a defined geographical area- an all-comers analysis. Seizure 92, 118-127. https://doi.org/https://doi.org/10.1016/j.seizure.2021.08.016

24. Megiddo, I., Colson, A., Chisholm, D., Dua, T., Nandi, A., Laxminarayan, R., 2016. Health and economic benefits of public financing of epilepsy treatment in India: An agent-based simulation model. Epilepsia 57, 464-474. https://doi.org/https://doi.org/10.1111/epi.13294

25. Mehmood, M., 2014. Use of Bioinformatics Tools in Different Spheres of Life Sciences. J. Data Mining Genomics Proteomics 5. https://doi.org/10.4172/2153-0602.1000158

26. Miller, M.P., Kumar, S., 2001. Understanding human disease mutations through the use of interspecific genetic variation. Hum. Mol. Genet. 10, 2319-2328.

27. Montojo, J., Zuberi, K., Rodriguez, H., Bader, G.D., Morris, Q., 2014. GeneMANIA: Fast gene network construction and function prediction for Cytoscape. F1000Research 3, 153. https://doi.org/10.12688/f1000research.4572.1

28. Murray, C.J.L., Vos, T., Lozano, R., Naghavi, M., Flaxman, A.D., Michaud, C., Ezzati, M., Shibuya, K., Salomon, J.A., Abdalla, S., Aboyans, V., Abraham, J., Ackerman, I., Aggarwal, R., Ahn, S.Y., Ali, M.K., Alvarado, M., 
Anderson, H.R., Anderson, L.M., Andrews, K.G., Atkinson, C., Baddour, L.M., Bahalim, A.N., Barker-Collo, S., Barrero, L.H., Bartels, D.H., Basáñez, M.-G., Baxter, A., Bell, M.L., Benjamin, E.J., Bennett, D., Bernabé, E., Bhalla, K., Bhandari, B., Bikbov, B., Bin Abdulhak, A., Birbeck, G., Black, J.A., Blencowe, H., Blore, J.D., Blyth, F., Bolliger, I., Bonaventure, A., Boufous, S., Bourne, R., Boussinesq, M., Braithwaite, T., Brayne, C., Bridgett, L., Brooker, S., Brooks, P., Brugha, T.S., Bryan-Hancock, C., Bucello, C., Buchbinder, R., Buckle, G., Budke, C.M., Burch, M., Burney, P., Burstein, R., Calabria, B., Campbell, B., Canter, C.E., Carabin, H., Carapetis, J., Carmona, L., Cella, C., Charlson, F., Chen, H., Cheng, A.T.-A., Chou, D., Chugh, S.S., Coffeng, L.E., Colan, S.D., Colquhoun, S., Colson, K.E., Condon, J., Connor, M.D., Cooper, L.T., Corriere, M., Cortinovis, M., de Vaccaro, K.C., Couser, W., Cowie, B.C., Criqui, M.H., Cross, M., Dabhadkar, K.C., Dahiya, M., Dahodwala, N., Damsere-Derry, J., Danaei, G., Davis, A., De Leo, D., Degenhardt, L., Dellavalle, R., Delossantos, A., Denenberg, J., Derrett, S., Des Jarlais, D.C., Dharmaratne, S.D., Dherani, M., Diaz-Torne, C., Dolk, H., Dorsey, E.R., Driscoll, T., Duber, H., Ebel, B., Edmond, K., Elbaz, A., Ali, S.E., Erskine, H., Erwin, P.J., Espindola, P., Ewoigbokhan, S.E., Farzadfar, F., Feigin, V., Felson, D.T., Ferrari, A., Ferri, C.P., Fèvre, E.M., Finucane, M.M., Flaxman, S., Flood, L., Foreman, K., Forouzanfar, M.H., Fowkes, F.G.R., Fransen, M., Freeman, M.K., Gabbe, B.J., Gabriel, S.E., Gakidou, E., Ganatra, H.A., Garcia, B., Gaspari, F., Gillum, R.F., Gmel, G., Gonzalez-Medina, D., Gosselin, R., Grainger, R., Grant, B., Groeger, J., Guillemin, F., Gunnell, D., Gupta, R., Haagsma, J., Hagan, H., Halasa, Y.A., Hall, W., Haring, D., Haro, J.M., Harrison, J.E., Havmoeller, R., Hay, R.J., Higashi, H., Hill, C., Hoen, B., Hoffman, H., Hotez, P.J., Hoy, D., Huang, J.J., Ibeanusi, S.E., Jacobsen, K.H., James, S.L., Jarvis, D., Jasrasaria, R., Jayaraman, S., Johns, N., Jonas, J.B., Karthikeyan, G., Kassebaum, N., Kawakami, N., Keren, A., Khoo, J.-P., King, C.H., Knowlton, L.M., Kobusingye, O., Koranteng, A., Krishnamurthi, R., Laden, F., Lalloo, R., Laslett, L.L., Lathlean, T., Leasher, J.L., Lee, Y.Y., Leigh, J., Levinson, D., Lim, S.S., Limb, E., Lin, J.K., Lipnick, M., Lipshultz, S.E., Liu, W., Loane, M., Ohno, S.L., Lyons, R., Mabweijano, J., Maclntyre, M.F., Malekzadeh, R., Mallinger, L., Manivannan, S., Marcenes, W., March, L., Margolis, D.J., Marks, G.B., Marks, R., Matsumori, A., Matzopoulos, R., Mayosi, B.M., McAnulty, J.H., McDermott, M.M., McGill, N., McGrath, J., Medina-Mora, M.E., Meltzer, M., Mensah, G.A., Merriman, T.R., Meyer, A.-C., Miglioli, V., Miller, M., Miller, T.R., Mitchell, P.B., Mock, C., Mocumbi, A.O., Moffitt, T.E., Mokdad, A.A., Monasta, L., Montico, M., Moradi-Lakeh, M., Moran, A., Morawska, L., Mori, R., Murdoch, M.E., Mwaniki, M.K., Naidoo, K., Nair, M.N., Naldi, L., Narayan, K.M.V., Nelson, P.K., Nelson, R.G., Nevitt, M.C., Newton, C.R., Nolte, S., Norman, P., Norman, R., O’Donnell, M., O’Donnell, M., O’Hanlon, S., Olives, C., Omer, S.B., Ortblad, K., Osborne, R., Ozgediz, D., Page, A., Pahari, B., Pandian, J.D., Rivero, A.P., Patten, S.B., Pearce, N., Padilla, R.P., Perez-Ruiz, F., Perico, N., Pesudovs, K., Phillips, D., Phillips, M.R., Pierce, K., Pion, S., Polanczyk, G. V, Polinder, S., Pope, C.A., Popova, S., Porrini, E., Pourmalek, F., Prince, M., Pullan, R.L., Ramaiah, K.D., Ranganathan, D., Razavi, H., Regan, M., Rehm, J.T., Rein, D.B., Remuzzi, G., Richardson, K., Rivara, F.P., Roberts, T., Robinson, C., De Leòn, F.R., Ronfani, L., Room, R., Rosenfeld, L.C., Rushton, L., Sacco, R.L., Saha, S., Sampson, U., Sanchez-Riera, L., Sanman, E., Schwebel, D.C., Scott, J.G., Segui-Gomez, M., Shahraz, S., Shepard, D.S., Shin, H., Shivakoti, R., Singh, D., Singh, G.M., Singh, J.A., Singleton, J., Sleet, D.A., Sliwa, K., Smith, E., Smith, J.L., Stapelberg, N.J.C., Steer, A., Steiner, T., Stolk, W.A., Stovner, L.J., Sudfeld, C., Syed, S., Tamburlini, G., Tavakkoli, M., Taylor, H.R., Taylor, J.A., Taylor, W.J., Thomas, B., Thomson, W.M., Thurston, G.D., Tleyjeh, I.M., Tonelli, M., Towbin, J.A., Truelsen, T., Tsilimbaris, M.K., Ubeda, C., Undurraga, E.A., van der Werf, M.J., van Os, J., Vavilala, M.S., Venketasubramanian, N., Wang, M., Wang, W., Watt, K., Weatherall, D.J., Weinstock, M.A., Weintraub, R., Weisskopf, M.G., Weissman, M.M., White, R.A., Whiteford, H., Wiebe, N., Wiersma, S.T., Wilkinson, J.D., Williams, H.C., Williams, S.R.M., Witt, E., Wolfe, F., Woolf, A.D., Wulf, S., Yeh, P.-H., Zaidi, A.K.M., Zheng, Z.-J., Zonies, D., Lopez, A.D., AlMazroa, M.A., Memish, Z.A., 2012. 
Disability-adjusted life years (DALYs) for 291 diseases and injuries in 21 regions, 1990-2010: a systematic analysis for the Global Burden of Disease Study 2010. Lancet (London, England) 380, 2197-2223.

https://doi.org/10.1016/s0140-6736(12)61689-4

29. Orenstein, N., Goldberg-Stern, H., Straussberg, R., Bazak, L., Weisz Hubshman, M., Kropach, N., Gilad, O., Scheuerman, O., Dory, Y., Kraus, D., Tzur, S., Magal, N., Kilim, Y., Shkalim Zemer, V., Basel-Salmon, L., 2018. A de novo GABRA2 missense mutation in severe early-onset epileptic encephalopathy with a choreiform movement disorder. Eur. J. Paediatr. Neurol. 22, 516-524.

https://doi.org/https://doi.org/10.1016/j.ejpn.2017.12.017

30. Owolabi, L.F., Owolabi, S.D., Adamu, B., Jibo, A.M., Alhaji, I.D., 2020. Epilepsy treatment gap in Sub-Saharan Africa: Meta-analysis of community-based studies. Acta Neurol. Scand. 142, 3-13.

https://doi.org/10.1111/ane.13246

31. Paul, A., Adeloye, D., George-Carey, R., Kolčić, I., Grant, L., Chan, K.Y., 2012. An estimate of the prevalence of epilepsy in Sub-Saharan Africa: A systematic analysis. J. Glob. Health 2, 20405. https://doi.org/10.7189/jogh.02.020405

32. Pejaver, V., Urresti, J., Lugo-Martinez, J., Pagel, K.A., Lin, G.N., Nam, H.-J., Mort, M., Cooper, D.N., Sebat, J., lakoucheva, L.M., Mooney, S.D., Radivojac, P., 2020. Inferring the molecular and phenotypic impact of amino acid variants with MutPred2. Nat. Commun. 11, 5918. https://doi.org/10.1038/s41467-020-19669-x

33. Robert, F., Pelletier, J., 2018. Exploring the Impact of Single-Nucleotide Polymorphisms on Translation.

34. Saih, A., Baba, H., Bouqdayr, M., Ghazal, H., Hamdi, S., Kettani, A., Wakrim, L., 2021. In Silico Analysis of High-Risk Missense Variants in Human ACE2 Gene and Susceptibility to SARS-CoV-2 Infection. Biomed Res. Int. 2021, 6685840. https://doi.org/10.1155/2021/6685840

35. Sanchis-Juan, A., Hasenahuer, M.A., Baker, J.A., McTague, A., Barwick, K., Kurian, M.A., Duarte, S.T., BioResource, N., Carss, K.J., Thornton, J., Raymond, F.L., 2020. Structural analysis of pathogenic missense mutations in GABRA2 and identification of a novel de novo variant in the desensitization gate. Mol. Genet. Genomic Med. 8, e1106. https://doi.org/10.1002/mgg3.1106

36. Sharma, D., Saini, A., Singh, D., 2020. SARS-CoV-2 whole-genome classification analysis, protein homology modelling and elucidation of associated protein functions. https://doi.org/10.31219/osf.io/9afp3

37. Shihab, H.A., Gough, J., Cooper, D.N., Day, I.N.M., Gaunt, T.R., 2013. Predicting the functional consequences of cancer-associated amino acid substitutions. Bioinformatics 29, 1504-1510.

https://doi.org/10.1093/bioinformatics/btt182

38. Siddiqui, F., Sultan, T., Mustafa, S., Siddiqui, S., Ali, S., Malik, A., Sajjad, Z., Barech, S., Jooma, R., 2015. Epilepsy in pakistan: national guidelines for clinicians. Pakistan J. Neurol. Sci. 10.

39. Sirven, J.I., 2015. Epilepsy: A Spectrum Disorder. Cold Spring Harb. Perspect. Med. 5, a022848. https://doi.org/10.1101/cshperspect.a022848

40. Sun, Y., Lu, L., Li, L., Wang, J., 2021. An advance about the genetic causes of epilepsy, in: E3S Web of Conferences. EDP Sciences, p. 3068.

41. Szklarczyk, D., Gable, A.L., Lyon, D., Junge, A., Wyder, S., Huerta-Cepas, J., Simonovic, M., Doncheva, N.T., Morris, J.H., Bork, P., Jensen, L.J., Mering, C. von, 2019. STRING v11: protein-protein association networks with increased coverage, supporting functional discovery in genome-wide experimental datasets. Nucleic Acids Res. 47, D607-D613. https://doi.org/10.1093/nar/gky1131

Page $11 / 17$ 
42. Szklarczyk, D., Gable, A.L., Nastou, K.C., Lyon, D., Kirsch, R., Pyysalo, S., Doncheva, N.T., Legeay, M., Fang, T., Bork, P., Jensen, L.J., von Mering, C., 2021. The STRING database in 2021: customizable protein-protein networks, and functional characterization of user-uploaded gene/measurement sets. Nucleic Acids Res. 49, D605-D612. https://doi.org/10.1093/nar/gkaa1074

43. Tang, H., Thomas, P.D., 2016. PANTHER-PSEP: predicting disease-causing genetic variants using positionspecific evolutionary preservation. Bioinformatics 32, 2230-2232.

https://doi.org/10.1093/bioinformatics/btw222

44. , T.J., Sander, J.W., 2019. Epilepsy in adults. Lancet 393, 689-701.

https://doi.org/https://doi.org/10.1016/S0140-6736(18)32596-0

45. Thusberg, J., Olatubosun, A., Vihinen, M., 2011. Performance of mutation pathogenicity prediction methods on missense variants. Hum. Mutat. 32, 358-368. https://doi.org/10.1002/humu.21445

46. Vallejos-Vidal, E., Reyes-Cerpa, S., Rivas-Pardo, J.A., Maisey, K., Yáñez, J.M., Valenzuela, H., Cea, P.A., CastroFernandez, V., Tort, L., Sandino, A.M., Imarai, M., Reyes-López, F.E., 2020. Single-Nucleotide Polymorphisms (SNP) Mining and Their Effect on the Tridimensional Protein Structure Prediction in a Set of ImmunityRelated Expressed Sequence Tags (EST) in Atlantic Salmon (Salmo salar.

47. Vaser, R., Adusumalli, S., Leng, S.N., Sikic, M., Ng, P.C., 2016. SIFT missense predictions for genomes. Nat. Protoc. 11, 1.

48. Warde-Farley, D., Donaldson, S.L., Comes, O., Zuberi, K., Badrawi, R., Chao, P., Franz, M., Grouios, C., Kazi, F., Lopes, C.T., Maitland, A., Mostafavi, S., Montojo, J., Shao, Q., Wright, G., Bader, G.D., Morris, Q., 2010. The GeneMANIA prediction server: biological network integration for gene prioritization and predicting gene function. Nucleic Acids Res. 38, W214-W220. https://doi.org/10.1093/nar/gkq537

49. Xing, J., Zhang, Y., Jing, W., Li, W.L., Yu, Y., 2019. MOLECULAR CHARACTERIZATION, EXPRESSION PATTERNS AND METHYLATION ANALYSIS OF ATP-BINDING CASSETTE SUB-FAMILY G MEMBER 2 (ABCG2) IN BROILERS. https://doi.org/10.13140/RG.2.2.30637.54242

\section{Tables}

Table (1): List of tools used to predict most pathogenic nsSNPs.

\begin{tabular}{|llll|}
\hline Tool & Threshold value & Prediction & URLs \\
\hline SIFT & $<0.05$ & Deleterious & https://sift-dna.org \\
\hline PROVEAN & $\leq 2.5$ & Deleterious & https://provean.jcvi.org/index.php \\
\hline PolyPhen-2 & 1.0 & Deleterious & https://genetics.bwh.harvard.edu/pph2/ \\
\hline PhD-SNP & $<0.5$ & Disease & https://snps.biofold.org/phd-snp/phd snp.html \\
\hline SNP\&GO & $>0.5$ & Disease & https://snps-and-go.biocomp.unibo.it/snps-and-go/ \\
\hline PANTHER & N/A & Probably/Possibly & https://www.pantherdb.org/tools/ \\
\hline & & damaging & \\
\hline
\end{tabular}


Table 2: Algorithms used to check the impact on protein stability.

\begin{tabular}{|llll|}
\hline Algorithms & Predict & URLs & References \\
\cline { 2 - 2 } & Protein stability & https://www.ics.uci.edu/ baldig/mutation.html & (Saih et al., 2021) \\
& & & (Pejaver et al., 2020) \\
MutPred & Protein stability & http://mutpred.mutdb.org/ & \\
\hline
\end{tabular}

Table 3:Output of nsSNPs predict as deleterious by all algorithms.

\begin{tabular}{|lllllllll|}
\hline SNP id & Substitution & SIFT & PROVEAN & Polyphen & Panther & SNP\&GO & $\begin{array}{l}\text { PhD- } \\
\text { SNP }\end{array}$ & FATHMM \\
\hline rs17852044 & V80A & T & D* & P.D & P.D & D & D & N/A \\
\hline rs41305781 & T43A & D* & D* & P.D & P.D & D & N & N/A \\
\hline rs41310789 & F285S & D* & D* & P.D & P.D & D & D & D! \\
\hline rs74440199 & T70I & D* & D* & P.D & P.D & N & D & N/A \\
\hline rs76519302 & P79S & D* & D* & P.D & P.D & N & D & N/A \\
\hline rs199725032 & F93C & D* & D* & P.D & P.D & D & D & N/A \\
\hline
\end{tabular}

$D *$ deleterious,P.D:probably damaging,N:neutral,D:disease,D!:damaging.

Table 4: Stability analysis results.

\begin{tabular}{|llll|}
\hline Mupro Score & Prediction & MutPred Score & Prediction \\
\hline-1.4209216 & Decrease & 0.946 & \\
& & & - Altered Ordered interface \\
& & - Altered Transmembrane protein \\
& & - A gain of Relative solvent accessibility \\
& & - A gain of O-linked glycosylation at F285. \\
& & & \\
& & & \\
& &
\end{tabular}

\section{Figures}




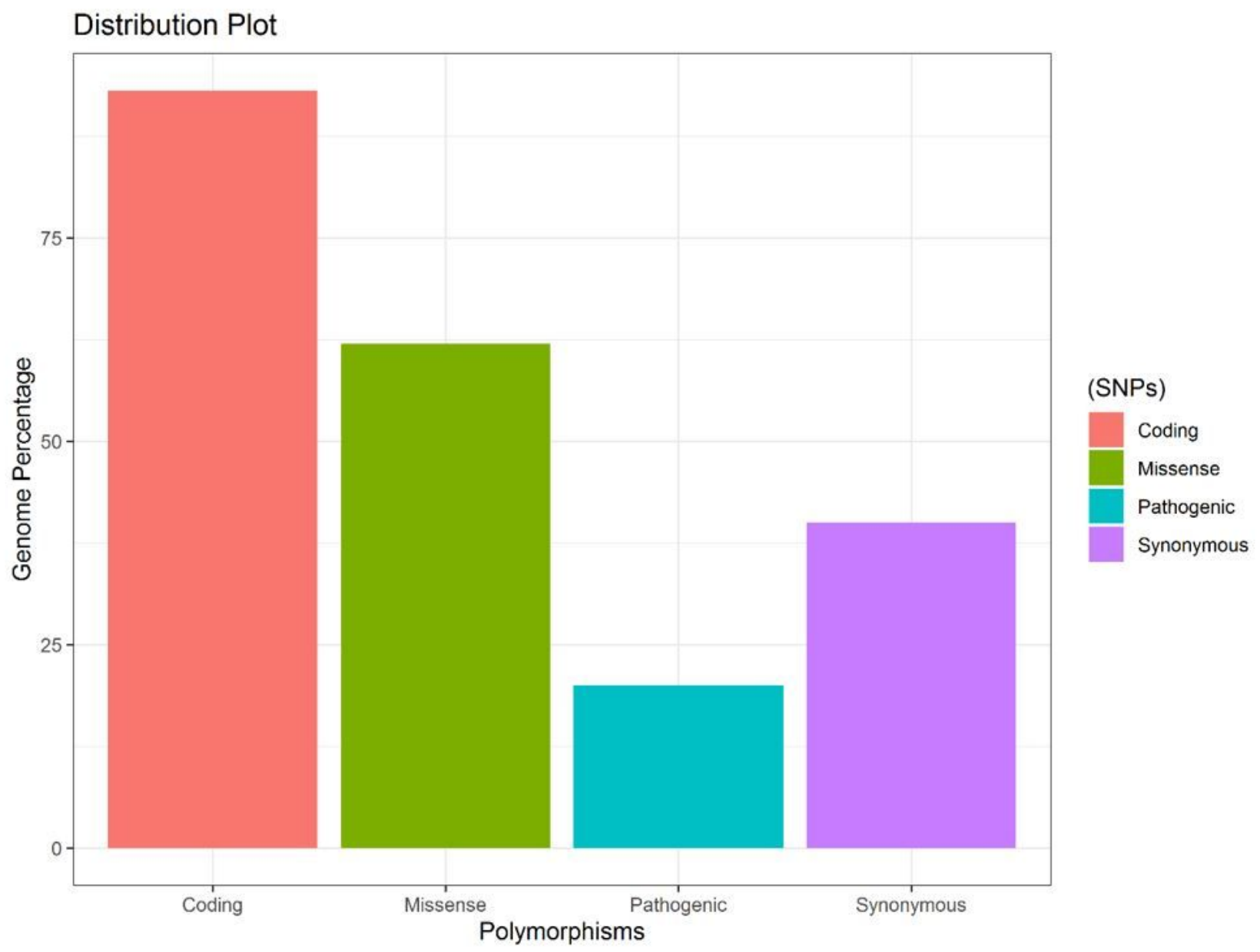

Figure 1

Distribution of GABRA2 SNPs present in human genome. 
f

251
EYFVIOTYuP CIYTVIISQV
bbbbbbbbbb bbbbbbbbbb
s s s s ss

301 311

RNSIPIVAYA TANWFIAVC

eeebeebbbb ebbebbbbbb

$f$ ffs $s$ fs $f$

361

351

NDKKKEIXASV

MIQNNAYAVA

eeeeeeeee eeereereee
271

SFW NTESV 281

tewhinesve ar

sss
281

ARTSSGVTTV

beblbblbbbb bbbbbbbeeb

331

sss ss s

YAFVFSAIIE FATVNYFTKR

bbbbbbbbbe

bbbbbbbbee

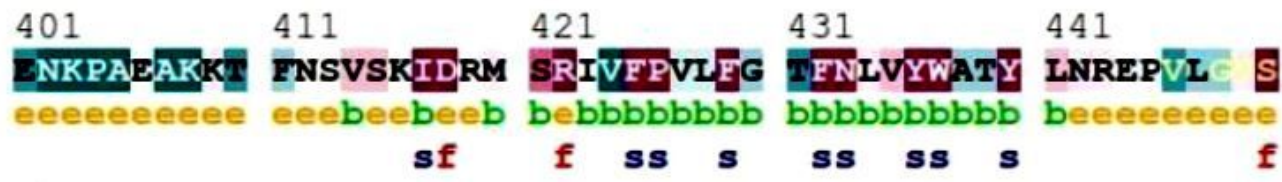

451

$\mathbf{P}$

e

Legend:

The conservation scale:

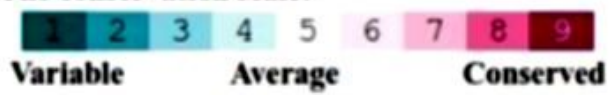

e - An exposed residue according to the neural-network algorithm.

$\mathrm{b}-\mathrm{A}$ buried residue according to the neural-network algorithm.

f - A predicted functional residue (highly conserved and exposed).

s - A predicted structural residue (highly conserved and buried).

X- Insufficient data - the calculation for this site was performed on less than $10 \%$ of the sequences.

Figure 2

Prediction of evolutionary conserved sites in GABRA2 gene by CONSURF database. 

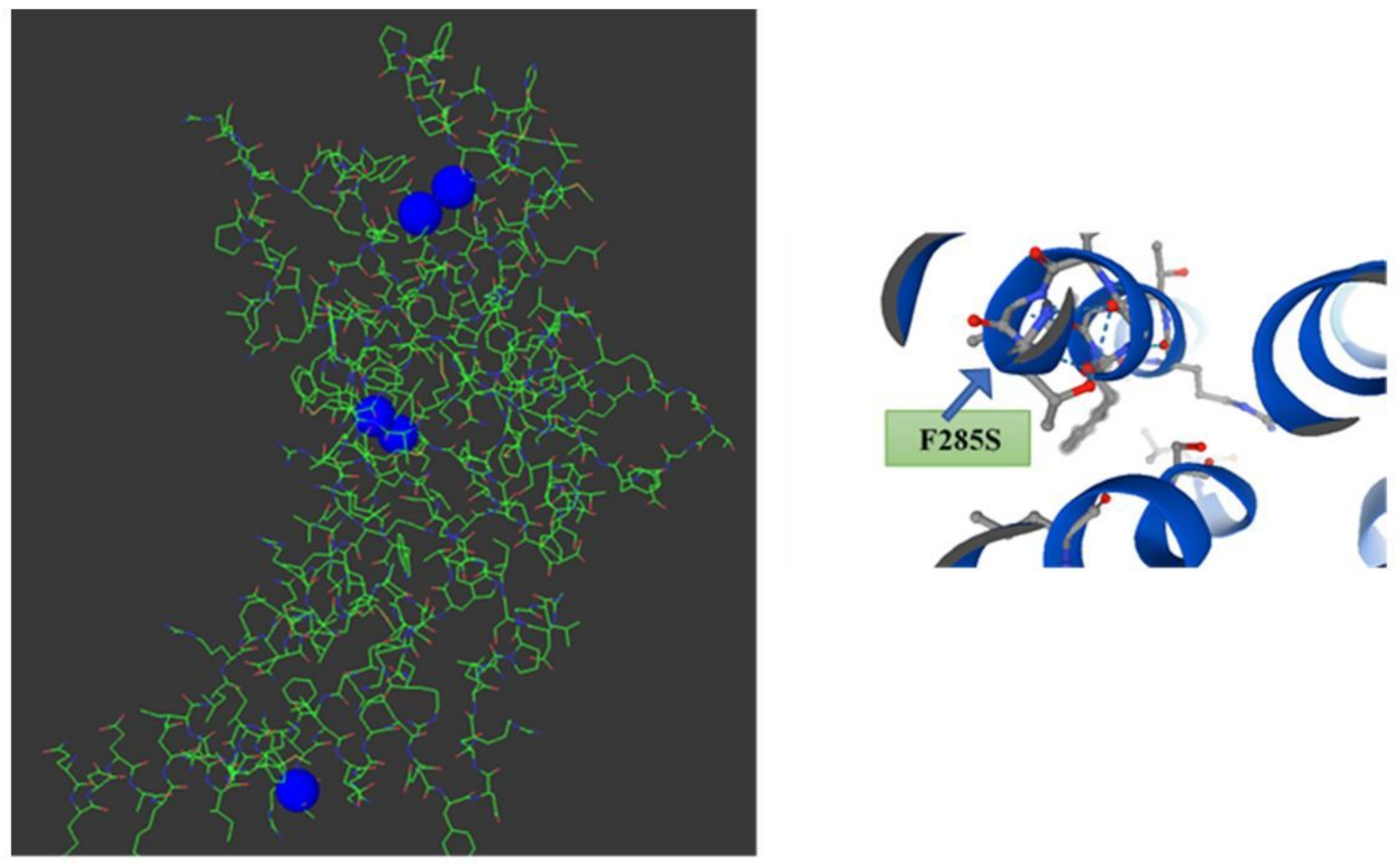

Figure 3

Location of mutations on mutant protein structure and location of F285S variant on alpha helix of protein. 


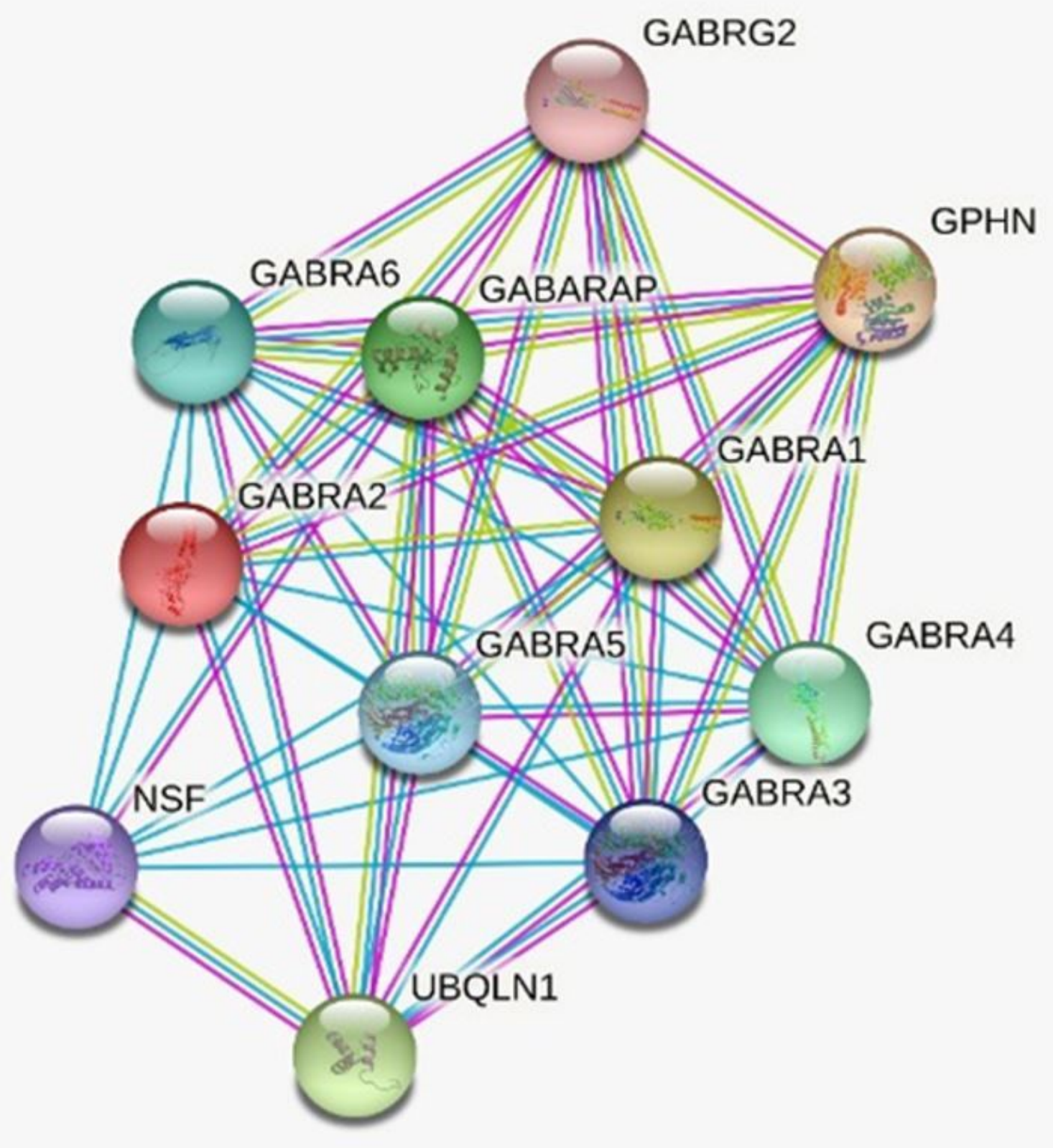

Figure 4

STRING database showed GABRA2 functionally interacts with other genes. 